\title{
Food toxicology and consumer health harm: a review
}

\author{
Dallynne Barbara Ramos Venancio ${ }^{1 *}$; Marcelo Arthur Dias da Costa Santana ${ }^{2}$ Ewerton de Carvalho \\ Nascimento $^{3}$; Hildenê de Jesus Oliveira ${ }^{4}$; Marcelo Francisco Galdino da Silva ${ }^{5}$; Ariany Rebeka \\ Salgado da Silva ${ }^{6}$; Maria Eduarda da Silva Torres ${ }^{7}$; Cristiane de Oliveira Vasconcelos ${ }^{8}$; Andriele Lais \\ da Silva Xavier ${ }^{9}$; Maria Paula de Lima Silva ${ }^{10}$; Nataly Luzinete Ferreira ${ }^{11}$; Maria Eduarda Barbosa \\ da Silva ${ }^{12}$; Maria Eduarda Nery da Silva ${ }^{13}$; Elianay Silva Lima ${ }^{14}$; Janequele Tavares da Silva ${ }^{15}$; \\ Patrícia Barbosa de Morais ${ }^{16}$
}

\begin{abstract}
1 Undergraduate bachelor's degree in Biomedicine at University Center of Vitória de Santo Antão - UNIVISA.
2 Undergraduate bachelor's degree in Biomedicine at University Center of Vitória de Santo Antão - UNIVISA.

3 Undergraduate bachelor's degree in Pharmacy at University Center of Vitória de Santo Antão - UNIVISA.

4 Undergraduate of the bachelor's degree in Nursing at University Center of Vitória de Santo Antão - UNIVISA.

5 Graduating from the bachelor's degree course in Pharmacy at University Center of Vitória de Santo Antão - UNIVISA.

6 Undergraduate bachelor's degree in Nursing at University Center of Vitória de Santo Antão - UNIVISA.

7 Undergraduate bachelor's degree in Nursing at University Center of Vitória de Santo Antão - UNIVISA.

8 Undergraduate bachelor's degree in Biomedicine at University Center of Vitória de Santo Antão - UNIVISA.

9 Undergraduate bachelor's degree in Nursing at University Center of Vitória de Santo Antão - UNIVISA.

10 Undergraduate nursing degree at University Center of Vitória de Santo Antão - UNIVISA.

11 Undergraduate nursing degree at University Center of Vitória de Santo Antão - UNIVISA.

12 Undergraduate nursing degree at University Center of Vitória de Santo Antão - UNIVISA.

13 Undergraduate nursing degree student at University Center of Vitória de Santo Antão - UNIVISA.

14 Undergraduate nursing degree at University Center of Vitória de Santo Antão - UNIVISA.

15 Undergraduate bachelor's degree in Biomedicine at UNIFAVIP

16 Undergraduate bachelor's degree in Nursing at University Center of Vitória de Santo Antão - UNIVISA.
\end{abstract}

E-mail adresses: (Dallynne Bárbara Ramos Venancio), marceloarthursantana@gmail.com (Marcelo Arthur Dias da Costa Santana), ewertoncarvalho1@gmail.com (Ewerton de Carvalho Nascimento), hildeneoliveira04@gmail.com (Hildenê de Jesus Oliveira), marcelo.fgs85@gmail.com (Marcelo Francisco Galdino da Silva), arianyrebekasalgado6@gmail.com (Ariany Rebeka Salgado da Silva), mariaeduardatorres020@gmail.com (Maria Eduarda da Silva Torres), cristiane.vasconcelos1@hotmail.com (Cristiane de Oliveira Vasconcelos), andrielelais40@gmail.com (Andriele Lais da Silva Xavier), mpaula17959@gmail.com (Maria Paula de Lima Silva), natalyferreira@outlook.com (Nataly Luzinete Ferreira), enfeduardabarbosa@gmail.com (Maria Eduarda Barbosa da Silva), Maria.201829007@univisa.edu.br (Maria Eduarda Nery da Silva), elianaylima21@gmail.com (Elianay Silva Lima), janequeletavares@gmail.com (Janequele Tavares da Silva),patriciabarbosab85@gmail.com (Patrícia Barbosa de Morais)

${ }^{*}$ Corresponding author

\section{To cite this article:}

Venancio, D.B.R.; Santana, M.A.D.C.; Nascimento, E.C.; Oliveira, H.J.; Silva, MF.G.; Silva, A.R.S.; Torres, M.E.S.; Vasconcelos, C.O.; Xavier, A.L.S.; Silva, M.P.L.; Ferreira, N.L.; Silva, M.E.B.; Silva, M.E.N.; Lima, E.S.; Silva, J.T.; Morais, P.B. Food toxicology and consumer health harm: a review. International Journal of Sciences. Vol. 2, No. 3, 2021, pp. 27-30. ISSN 2763-5392.

Received: 10 09, 2021; Accepted: 10 10, 2021; Published: 11 03, 2021

\begin{abstract}
Food Toxicology studies the toxicity of food-bound substances, determining the presence, concentration and origin of the chemical in food, factors that influence its appearance and reversibility, as well as the harmful effects on consumer health. This is a descriptive study with a qualitative approach, carried out through a bibliographic survey related to the theme "Food toxicology: food additives". Most foods of plant or animal origin deteriorate easily, losing quality with consequent decrease in shelf life. Companions of preservatives, antioxidants are substances that delay the appearance of oxidative changes in food. Most of these products contain food additives, mainly dyes, preservatives and artificial antioxidants, which can bring health risks.
\end{abstract}


2 Venancio, D.B.R.; Santana, M.A.D.C.; Nascimento, E.C.; Oliveira, H.J.; Silva, MF.G.; Silva, A.R.S.; Torres, M.E.S.; Vasconcelos, C.O.; Xavier, A.L.S.; Silva, M.P.L.; Ferreira, N.L.; Silva, M.E.B.; Silva, M.E.N.; Lima, E.S.; Silva, J.T.; Morais, P.B. Food toxicology and consumer health harm...

It is important to point out that information about the risks and dangers of food additives in doses above that recommended by the National Health Surveillance Agency (ANVISA) should be passed on to the population, which is often unaware of the effects caused on human health.

Keywords: Toxicology. Additives. Food. Consumer health.

\section{Introduction}

The food toxicology of the emphasis on studies of toxic substances present in foods are of natural or synthetic origin, in toxicology also study the conditions that food can be ingested without causing harm to the body. Food additives are substances used for the purpose of changing the physical, chemical, biological or sensory characteristics during processing of a food, however these additives do not contain any nutritional action. They are classified as incidents and intentional, among them we highlight several, such as: preservatives, antioxidants, dyes, flavorings among others.

Since the beginning of humanity, man used techniques that guaranteed the conservation of food, and consequently avoided the waste of these. Currently, in addition to making use, for example, of the refrigerator, freezer, pasteurization, man uses chemical substances that prolong the shelf life of food and highlight its sensory characteristics (SANTOS, 2008).

With the change in the eating habits of the Brazilian population in recent decades, due to urbanization and the fast pace of daily life, consumers tend to prefer ready-to-eat or semi-ready foods that favor practicality. Thus, there was an incidence of a higher number of chronic non-communicable diseases (systemic arterial hypertension, obesity, diabetes mellitus, allergies) due to the higher use formalized industry foods (processed and ultra-processed), replacing fresh foods. Due to these changes, the industry is increasingly seeking to improve its products to satisfy the consumer and thus generate for-profit (POLONIUM; PERES, 2009; BISSACOTTI; ANGST; SACCOL, 2015).

\section{Methodology}

The review of narrative or traditional literature, when compared to the systematic review, presents a more open theme. Hardly part of a specific well-defined issue, not requiring a rigid protocol for its preparation and the search for sources is not predetermined and specific, being often less comprehensive. The selection of articles is arbitrary, providing the author of information subject to selection bias, with great interference of subjective perception (CORDEIRO, 2012).

This is an exploratory-descriptive study with a qualitative approach, carried out through a bibliographic survey and the use of secondary data from publications related to the theme "Food toxicology: food additives". In view of this approach, the objective of this research is to make a bibliographic survey, on the topics such as the importance of food toxicology, how it is being used, the malefactors to the consumer. The descriptors used were: Toxicology; Additives; Food; Consumer health. Several sources were used such as books, scientific articles, master's dissertations and legislation.

\section{Results and Discussion}

In the past, food was manufactured and produced in the same region or regions close to those of commercialization. Currently, with the globalization and development of logistics at national and international level, most food from distant regions often needs additives and preservatives for its integrity (AISSA, 2010).

With the benefit of the advance of the chemical industry, the food industry started to use a large number of additives in food, to improve storage conditions and offer safe food, and thus meet the expectations of the consumer market (REZENDE; BIRTH; PIOCHON, 2008). In addition to economic stability, other factors such as women's work outside the home, greater practicality, speed, durability and good product acceptance have increasingly contributed to the introduction and maintenance of industrialized foods in the eating habits of consumers of all ages (AQUINO; PHILIPPI, 2002).

Ordinance No. 540 - SVS/MS of October 27, 1997 defines that food additive "is any ingredient intentionally added to food, without the purpose of nourishing, but with the objective of modifying the physical, chemical, biological or sensory characteristics, during the manufacture, processing, preparation, treatment, packaging, packaging, storage, transportation or handling of a food. Adding may result in the additive itself or its derivatives becoming a component of such food this definition does not include contaminants or nutritional substances that are incorporated into food to maintain or improve its nutritional properties" (BRASIL, 1997).

\section{Preservatives}

Most foods of plant or animal origin deteriorate easily, losing quality with consequent decrease in shelf life. These losses depend on several factors, including the type, composition, formulation, packaging and storage condition of food. The main form of food deterioration is of microbial origin (MELO, 2005).

Food preservatives are substances that, added to a particular food, prevent or delay changes caused by the action of microorganisms, enzymes and/or physical agents. Currently, conservatives are increasingly being used by the food industry, since there is a growing demand for chemically stable and safe foods, with greater durability 
(TONETTO et al., 2008). The most used preservatives are: sulfur dioxide, benzoic acid, sorbic acid, propionic acid in free form, or sodium or potassium salts and nitrites and nitrates of sodium and potassium (ARAÚJO, 2009).

Although essential as an additional method for food conservation in the current panorama, the limitation and decreasing policy of the use of chemical preservatives in food are related to the toxicological risk that these compounds represent to consumer health (FAI; Stamford; STAMFORD, 2008). In addition, it is worth mentioning that the use of sodium salts as conservatives increases the daily consumption of this mineral, which can be harmful to human health by the correlation of sodium with arterial hypertension (PEREIRA; GALVAO; ZANELLA, 2005).

\section{Antioxidants}

Companions of preservatives, antioxidants are substances that delay the appearance of oxidative changes in food. In the industrial sector they are commonly used to maintain food preservation by delaying deterioration, rancidity and discoloration resulting from self-oxidation, especially in fatty foods (MESSIAS, 2009).

By definition, antioxidant activity is the ability of a compound to inhibit oxidative degradation. Thus, antioxidant activity, especially inhibition of chain reaction, of natural products and foods has been an important parameter in determining their dietary value. Interest in the discovery of new and safe antioxidants from natural sources has increased, primarily to prevent oxidative damage to living cells. The use of synthetic antioxidants has decreased due to suspected activity as promoters of carcinogenesis. The role of dietary antioxidants and their health benefits have attracted great attention from the academic community in recent years, especially those extracted from plants (LIMA et al., 2010).

Synthetic antioxidants are used as food additives to prevent or delay lipid oxidation. They are substances whose use was approved in food after investigations that proved their safety within a daily intake limit; therefore, they are subject to country-specific laws or international standards. Of these synthetic antioxidants the most used by the Brazilian industry are: butyl hydroxyanisol (BHA), butyl hydroxytoluene (BHT), propyl gallate (PG) and terc-butyl hydroquinone (TBHQ) (TAKEMOTO; SON; GODOY, 2009).

Among the most used natural antioxidants can be cited tocopherols, phenolic acids and plant extracts such as rosemary and sage. Tocopherol, as one of the best natural antioxidants is widely applied as a means to inhibit the oxidation of edible oils and fats, preventing oxidation of unsaturated fatty acids. Brazilian legislation allows the addition of $300 \mathrm{mg} / \mathrm{kg}$ of tocopherols in oils and fats, as intentional additives, with antioxidant function (RAMALHO; JORGE, 2006).

\section{Dyes}

The maintenance of the natural color of the food was a fundamental factor for the acceptance of the product, in view of the first evaluation of the consumer. Before the palate, colorful foods seduce people by sight. The logic of consuming these products begins with the eyes: colorful, showy, attractive foods can only be delicious. In general, the importance of the appearance of the product for its acceptability is the greatest justification for the use of dyes (PRADO; GODOY, 2007).

There has been discussion about the toxicity of synthetic dyes and the risks they can cause to health. They are usually associated with the mode and time of exposure to dyes. Many of the health problems, such as allergies, rhinitis, constriction scolding, hyperactivity, chromosomal damage, tumors, among others, have been reported by several authors (MARMITT; PIROTTA; STÜLP, 2010).

\section{Health and food harm}

Currently, it has been observed that in parallel to the consumption of basic foods there is the introduction of industrialized products, from the stimulation of the marketing of industries, with emphasis on the consumption of instant noodles, chocolate milk, yogurts, stuffed cookies, salted cookies and soft drinks. Television ads encourage the purchase of certain foods that are typically high energy density (sucrose and trans and saturated fats) and low nutritional value (Garcia, 2003). In addition, most of these products contain food additives, mainly artificial dyes, preservatives and antioxidants, which can bring health risks.

As already mentioned, the higher the consumption of industrialized foods, the greater the intake of chemical additives, however, it is impossible to predict the toxicity promoted, thus, the effects generated in the body due to the consumption of additives are still researched, but it is known that there are cases of allergies, cancer and disorders in the digestive system (BRASIL, 2007).

Another side effect is food hypersensitivity, divided into allergies and food intolerances, being considered the most common harmful effect promoted by additives. This manifestation is characterized by reactions triggered by the body to combat a substance present in a food, and there is a higher prevalence in children due to the consumption of industrialized products (POLONIUM; PERES, 2009).

It is recommended that in order to reduce the exposure to chemical additives it is necessary to diversify the brands of industrialized foods consumed, so that there is a variation in the number of substitutes and decreased exposure to them (SANTOS, 2008).

\section{Conclusions}

From the technological innovation of the industries there were concomitant changes in the modification of the eating habits of the population, which brought with its higher consumption of industrialized foods, causing several health consequences, such as the emergence of different types of diseases or complications caused by the exacerbated use of food additives. The higher the amount and frequency of foods containing these substances, the greater the intake of food chemical additives, which can become a major public 
4 Venancio, D.B.R.; Santana, M.A.D.C.; Nascimento, E.C.; Oliveira, H.J.; Silva, MF.G.; Silva, A.R.S.; Torres, M.E.S.; Vasconcelos, C.O.; Xavier, A.L.S.; Silva, M.P.L.; Ferreira, N.L.; Silva, M.E.B.; Silva, M.E.N.; Lima, E.S.; Silva, J.T.; Morais, P.B. Food toxicology and consumer health harm...

health problem, because they have cumulative effect on the body over time and do not predict the degree of toxicity promoted by them. The use of additives, however, is necessary for the improvement of the product to be marketed in relation to organoleptic characteristics and shelf life, thus ensuring food and nutritional safety, preventing the risks of microbial contamination in food.

It is important to point out that information about the risks and dangers of food additives in doses above that recommended by the National Health Surveillance Agency (ANVISA) should be passed on to the population, which is often unaware of the effects caused on human health, emphasizing how much more critical the consumer should be when choosing food. Review articles, such as this one, aim to guide and cover the knowledge of the population about specific topics, highlighting the importance of continuing new studies.

\section{References}

[1] AISSA, AF. Avaliação da atividade antimutagênica do betacaroteno micro encapsulado em células de ratos tratados com o antitumoral doxorrubicina empregado os ensaios de micronúcleo e cometa. São Paulo: Faculdade de ciências Farmacêuticas da Universidade de São Paulo; 2010.

[2] AQUINO, R.C.; PHILIPPI, S.T. Consumo infantil de alimentos industrializados e renda familiar na cidade de São Paulo. Revista de Saúde Pública, v.36, p.655-660, 2002.

[3] BRASIL. Ministério da Educação. Secretaria de Educação Básica. Módulo 11: Alimentação saudável e sustentável. Brasília: Universidade de Brasília, 2007.

[4] BRASIL. Ministério da Saúde (Brasil). Agência Nacional de Vigilância Sanitária. Legislação. Portaria $n^{\circ} 540$, de 27 de outubro de 1997. Aprova o Regulamento Técnico: Aditivos Alimentares - definições, classificações e emprego.

[5] CORDEIRO, A.M. Revisão sistemática: uma revisão narrativa. Revista. Col. Bras. Cir., v.34, n. 6,2012.

[6] FAI, A.E.C.; STAMFORD, T.CM.; STAMFORD, T.L.M. Potencial Biotecnológico de quitosana em sistemas de conservação de alimentos. Revista Ibero Polímeros. v.9, n.5, p. 10-15, abr, 2008.

[7] Garcia, R.W.D. Reflexos da globalização na cultura alimentar: considerações sobre as mudanças na alimentação urbana. Revista Nutrição, p.483-492, 2003.

[8] ISSACOTTI, A. P.; ANGST, C. A; SACCOL, A. L de F. Implicações dos aditivos químicos na saúde do consumidor. Revista Disciplinarum Scientia, Série: Ciências da Saúde, Santa Maria, v. 16, n. 1, p. 43-59, 2015.

[9] LIMA, A.R. ; et al. Compostos bioativos do café: atividade antioxidante in vitro do café verde e torrado antes e após a descafeinação. Revista Quím Nova, v.33, n.1, p.20-24, 2010.

[10] MARMITT, S.; PIROTTA, L.V.; STÜLP, S. Aplicação de fotólise direta e UV/H2O2 a efluente sintético contendo diferentes corantes alimentícios. Revista Química, v.33, n.2, p.384-8, 2010.
[11] MELLO, N.R.; SOARES, N.F.F.; GONÇALVES, M.P.J. Nisina: Um conservante natural para alimentos. Revista Ceres, v.52, p.921-938, 2005.

[12] MESSIAS, K. L. S. Os antioxidantes. Dossiê antioxidantes. Food Ingredients Brasil, n. 6, 2009.

[13] PEREIRA, M. A. G.; GALVAO, R; ZANELLA, M. T. Efeitos da suplementação de potássio via sal de cozinha sobre a pressão arterial e a resistência à insulina em pacientes obesos hipertensos em uso de diuréticos. Revista de Nutrição, v.18, n.1, p. $5-17,2005$.

[14] POLÔNIO, M. L. T.; PERES, F. Consumo de aditivos alimentares e efeitos à saúde: desafios para a saúde pública brasileira. Caderno de Saúde Pública, v. 25, n. 8, p. 1.653-1.666, 2009.

[15] PRADO, M. A.; GODOY, H. T. Teores de corantes artificiais em alimentos determinados por cromatografia líquida de alta eficiência. Revista Química Nova, v. 30, n.2, p. 268-273,2007.

[16] RAMALHO, V.C.; JORGE, N. Antioxidantes utilizados em óleos, gorduras e alimentos gordurosos. Revista Química Nova, v.29, n.4, p.755-760, 2005.

[17] REZENDE, S.; NASCIMENTO, D.; PIOCHON, E. Educação alimentar: aditivos alimentares encontrados nos sucos consumidos pelos acadêmicos do curso de ciências biológicas de Jataí - GO. In: Anais dos Congressos de Pedagogia. Jataí; 2008.

[18] SANTOS, R. M. P.; SANTOS, S. A. O ensino do tema aditivos químicos com o apoio de mapas conceituais e fluxogramas na sétima série do ensino fundamental. 2008.

[19] TAKEMOTO, E.; FILHO, J.T.; GODOY, H.T. Validação de metodologia para a determinação simultânea dos antioxidantes sintéticos em óleos vegetais, margarinas e gorduras hidrogenadas por clae/uv. Revista Química Nova, v.32, n., p.1189-1194, 2009.

[20] TONETTO, A.; et al. O Uso de Aditivos de Cor e Sabor em Produtos Alimentícios. Tecnologia de Alimentos. São Paulo: Faculdade de ciências farmacêuticas, nov.2008. 